\title{
Strandings of sea turtles on beaches around the oil capital in Brazil
}

\author{
Raísa da Silva Costa Rêgo', Eric Azevedo Cazetta', \\ Caio Henrique Gonçalves Cutrim ${ }^{1}$, Amanda Soares Miranda', \\ Ana Paula Albano Araújo², Vinícius Albano Araújo
}

1 Instituto de Biodiversidade e Sustentabilidade (NUPEM), Universidade Federal do Rio de Janeiro, Macaé, Rio de Janeiro, Brazil

2 Laboratório de Interações Ecológicas, Departamento de Ecologia, Centro de Ciências Biológicas e da Saúde, Universidade Federal de Sergipe, São Cristóvão, Sergipe, Brazil

Corresponding author: Vinícius Albano Araújo (vialbano@gmail.com)

Academiceditor:AnaMariaLeal-Zanchet |Received 14May2021 |Accepted2October2021|Published 17December2021

Citation: da Silva Costa Rêgo R, Cazetta EA, Cutrim CHG, Miranda AS, Araújo APA, Araújo VA (2021) Strandings of sea turtles on beaches around the oil capital in Brazil. Neotropical Biology and Conservation 16(4): 521-538. https://doi.org/10.3897/neotropical.16.e68662

\begin{abstract}
The south-western region of the Atlantic Ocean has feeding and nesting areas for the five species of sea turtles registered in Brazil, which are in different degrees of extinction threat, mainly due to anthropogenic factors. Fishing and the ingestion of solid waste, were identified as causing stranding and the mortality of sea turtles. In this work, data from the monitoring of beaches in the Municipalities of Macaé and Rio das Ostras, important oil zone in Brazil, in the north-central region of the State of Rio de Janeiro, were used in order to analyse the effects of seasonality on the sea turtle stranding. The monitoring was carried out daily from September 2017 to June 2019, in a study area covering $23.8 \mathrm{~km}$ long beach. Stranding data were obtained from active $(n=126)$ and passive $(n=66)$ monitoring of beaches and included the records of Chelonia mydas $(\mathrm{n}=151)$, Caretta caretta $(\mathrm{n}=23)$, Lepidochelys olivacea $(\mathrm{n}=14)$, Dermochelys coriacea $(\mathrm{n}=2)$ and Eretmochelys imbricata $(\mathrm{n}=1)$. The largest stranding record occurred in the summer $(n=61)$ and spring $(n=60)$, a period compatible with the reproductive season of the species. The results obtained in this study emphasise the importance of the analysis of strandings of sea turtles, which provide relevant data on the biology of the group, the intra and interspecific dynamics and the state of conservation of these animals.
\end{abstract}

\section{Keywords}

Anthropogenic impact, Campos Basin, conservation, endangered species, green turtle, south-western Atlantic 


\section{Introduction}

The current fauna of sea turtle corresponds to seven species, of which five species are present on the Brazilian coast (Pupo et al. 2006; Macêdo et al. 2015). All species found in Brazil are threatened, varying between vulnerable (Caretta caretta Linnaeus, 1758, Dermochelys coriacea Vandelli, 1761 and Lepidochelys olivacea Eschscholtz, 1829), endangered (Chelonia mydas Linnaeus, 1758) and critically endangered (Eretmochelys imbricata Linnaeus, 1766), according to International Union for Conservation of Nature (IUCN 2021) or the Brazilian Red Book of Threatened Species of Fauna (Chico Mendes Institute for Biodiversity Conservation/ Ministry of Environment - ICMBio/MMA 2018). These five species frequent the coast of the State of Rio de Janeiro (Santos et al. 2011; Reis et al. 2017; Werneck et al. 2018; Tagliolatto et al. 2019a), a region identified as an important spawning site for the C. caretta (Marcovaldi and Chaloupka 2007) and a foraging habitat, mainly for juveniles of C. mydas (Almeida et al. 2011; Awabdi et al. 2013; Reis et al. 2017; Guimarães et al. 2018; Tagliolatto et al. 2019a).

Sea turtles have a long-life cycle and can take 15 to 40 years to reach sexual maturity (Castilhos et al. 2011; Marcovaldi et al. 2011). Most turtle feeding, breeding and nesting activities occur in coastal regions, where the highest demographic densities are concentrated. Thus, the unsustainable use of natural resources in the coastal zone has caused adverse effects on the biology of sea turtles (Santos et al. 2011; Senko et al. 2014; Reis et al. 2017; Tagliolatto et al. 2019b). The main anthropogenic threats include bycatch, egg collection, running over and compaction of nests by vehicle traffic on the beaches, artificial lighting in spawning areas, pollution by solid waste or organic compounds, habitat degradation and dredging in the construction of industrial structures onshore and offshore (Marcovaldi et al. 2011; Goldberg et al. 2015; Reis et al. 2017; Ylitalo et al. 2017; Tagliolatto et al. 2019b).

Analysis of sea turtle stranding data is an important source of information on species biology, as spawning areas and feeding sites, in addition to providing subsidies for implementing sustainable practices and conservation plans (Santos et al. 2011; Poli et al. 2014; Senko et al. 2014; Reis et al. 2017; López-Mendilaharsu et al. 2020). The registration of stranded marine organisms has been recurrent on the coast of Brazil (Coelho 2009; Lopes-Souza et al. 2015; Monteiro et al. 2016) including the Rio de Janeiro State (Reis et al. 2009, 2010, 2017; Carvalho et al. 2015; Werneck et al. 2018; Tagliolatto et al. 2019a), due to the efforts of beach monitoring projects and the constant threats to the diverse populations in the marine ecosystem. Amongst the main causes of sea turtle strandings are fishing activities and solid waste ingestion (Kotas et al. 2004; Pupo et al. 2006; Kannan 2008; López-Mendilaharsu et al. 2009; Vélez-Rubio et al. 2013; Tagliolatto et al. 2019b).

The beach monitoring data from this study were used on an extension of the north-central coast of the Rio de Janeiro State, in order to: (i) analyse the effects of seasonality on the number of species and abundance of stranded sea turtles; (ii) evaluate the sex ratio and the developmental stage of stranded sea turtles; (iii) analyse 
whether the size of the beaches interferes with the number of stranding and (iv) to evaluate whether there is a relationship between anthropogenic factors, such as fishing activities and abundance of stranded sea turtles.

\section{Materials and methods}

\section{Study site}

The study was developed by analysing the sea turtle strandings on the beaches located in the Municipality of Rio das Ostras $\left(22^{\circ} 31^{\prime} 37^{\prime \prime} \mathrm{S}, 41^{\circ} 56^{\prime} 42^{\prime \prime} \mathrm{W}\right)$ in the Lagos region and in the Municipality of Macaé $\left(22^{\circ} 22^{\prime} 15^{\prime \prime} \mathrm{S}, 41^{\circ} 47^{\prime} 13^{\prime \prime} \mathrm{W}\right)$ in the northern region of the State of Rio de Janeiro, Brazil (Fig. 1). Macaé and Rio das Ostras are neighbouring Municipalities with an estimated population of approximately 416.7 thousand inhabitants (IBGE 2020) and have economies based on oil and natural gas exploration. The on- and offshore industries' activities contributed to the further development of the Municipalities and impacted tourism in these regions.

The following beaches were monitored: Cemitério, Centro, Itapebussus, Joana, Mar do Norte, Tartaruga and Virgem (Rio das Ostras) and Barra de Macaé, Campista, Cavaleiros, Farol, Forte, Imbetiba, Imboassica and Macaé (Macaé), spanning approximately $23.8 \mathrm{~km}$ of monitored beaches.

\section{Fauna monitoring and recording}

Sea turtle stranding records data were used and made available to the public domain through the Campos Basin and Espírito Santo Beach Monitoring Project (PMP-BC/ES). This project was started by the company Petrobras, as a condition imposed by the Brazilian Institute of the Environment and Renewable Natural Resources (IBAMA-Brazil) to obtain environmental licensing for the production and disposal of oil and natural gas. The data analysed were related to the monitoring of the beaches carried out between September 2017 and June 2019 and were obtained from the SIMBA database (Aquatic Biota Monitoring Information System).

The analysed beaches were monitored daily between 6:00 am and 12:00 am, walking along its length or with the assistance of motorised quadricycles. In addition to active and regular monitoring on the beaches, extensive contact was made to mobilise the passive (or indirect) monitoring method, in which the population informs about the location of stranded marine animals. People call to the free call centre (0800) and the team asks the informant to explain the location of the beach (name of the beach, tourist spot), which animal, the state of the animal. The informant is then instructed on how to retain the animal or carcass and the expected arrival of the team at the site. There is no operational base for receiving animals. All calls are made through the 0800 centre, from where the team travels to the location reported by the informant to answer the call. In both monitoring 

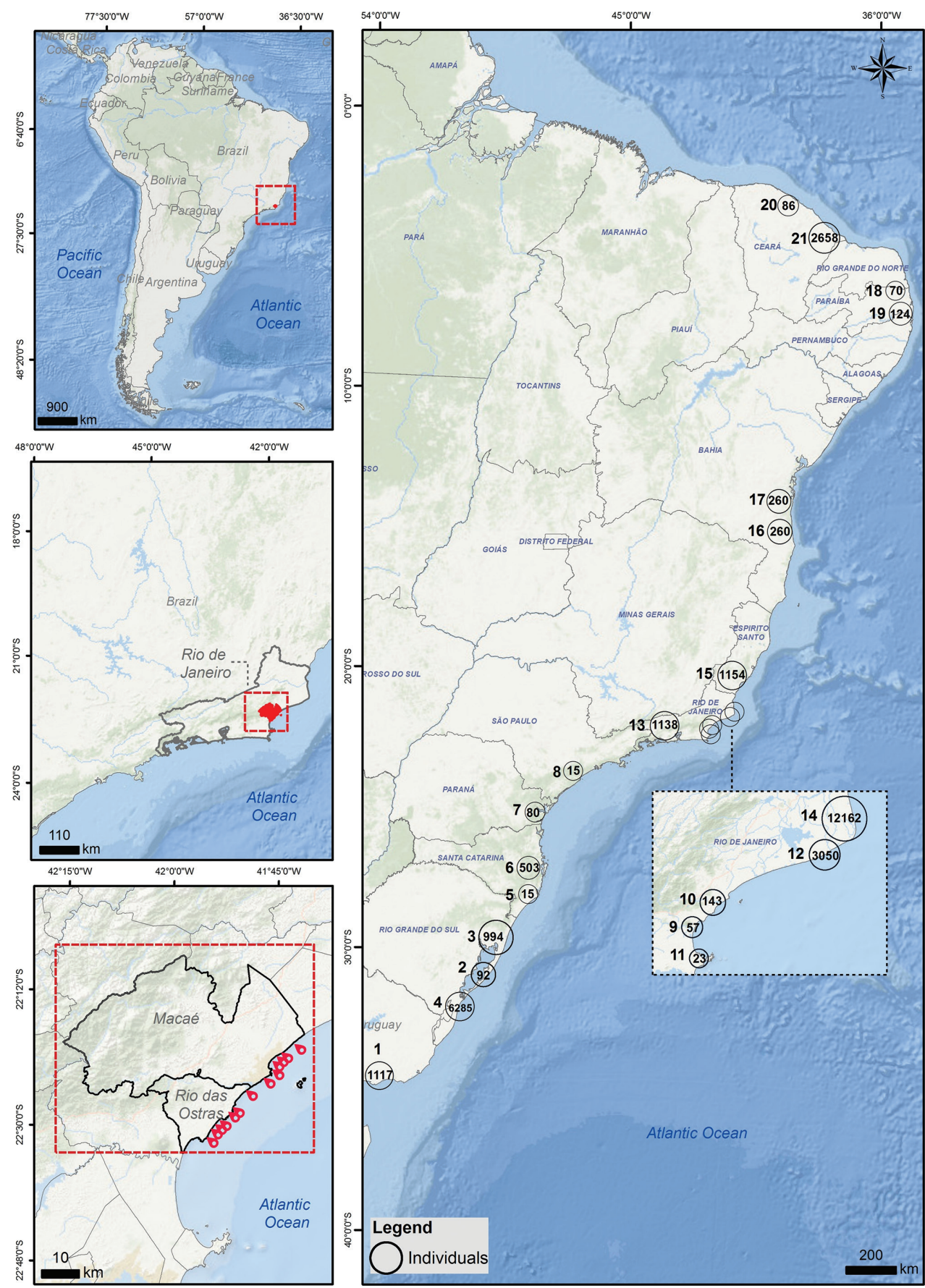

Figure 1. Geographic location map of the study area showing the Municipalities of Rio das Ostras and Macaé on the coast of the State of Rio de Janeiro, Brazil. The numbers 1 to 21 refer to the literature cited in Table 2 and, within the circles, the number of sea turtle strandings in each of the works along the coast of the south-western Atlantic Ocean is indicated. 
methods, data related to location, beach, time of monitoring duration and geographical coordinates were recorded.

For each stranded sea turtle, the following were recorded: the state of the animal (alive or dead), carcass conservation status, species identification, based on the morphology of the stranded animals, such as number of plates on the carapace, sex through observation of organs genitals or anatomopathological examination and stage of development (juvenile/adult) according to the measurements of the curvilinear carapace length (CCL). Adults were considered individuals having measurement of curvilinear carapace length (CCL) greater than or equal to $(\geq)$ the established values: Dermochelys coriacea $\geq 139 \mathrm{~cm}$ (Thomé et al. 2007), Chelonia mydas $\geq 90 \mathrm{~cm}$ (Almeida et al. 2011), Eretmochelys imbricata $\geq 86 \mathrm{~cm}$ (Marcovaldi and Marcovaldi 1999), Caretta caretta $\geq 83 \mathrm{~cm}$ (Baptistotte et al. 2003) and Lepidochelys olivacea $\geq 63 \mathrm{~cm}$ (Silva et al. 2007). The evaluation of the carcass conservation status was carried out, based on the classification created by Geraci and Lounsbury (2005) for marine mammals, where five categories are used to define the state of the animal found: 1) animal still alive; 2) carcass in initial decomposition state; 3 ) the state of the organism is moderately decomposed; 4) the animal in an advanced state of decomposition; 5) mummified organism or when only bones are found.

To determine the influence of fishing activity on stranding and commonly in the death of sea turtles, five categories were used (total evidence, very strong, strong, without evidence and undetermined/not examined) defined by the Tamar project protocol (Marcovaldi and Freitas 2000) (Table 1).

\section{Statistical analysis}

Descriptive analysis was carried out independently to verify the variation in the number of species and in the abundance of stranded turtles (dependent variables) in relation to season (independent variables) using Quasi-Poisson distribution. The seasons were defined as follows: summer (January to March), autumn (April to June), winter (July to September) and spring (October to December). To analyse the effects of beaches, the abundance and number of species data for each season, considering the entire period studied, they were used as repetition in the models. Differences between the means were analysed using the Tukey test $(P \leq 0.05)$. To analyse the

Table 1. Categories referring to the degree of interaction of the organism with fishing according with the protocol proposed by the marine turtle monitoring and conservation programme in Brazil, Projeto Tamar (Marcovaldi and Freitas 2000). The "observed" column refers to the number of turtles stranded in the present study and classified in the category described.

\begin{tabular}{lcc}
\hline \multicolumn{1}{c}{ Interaction degree } & Description & Observed \\
\hline Total evidence & Presence of fishing gear on the animal's body & $\mathrm{n}=8 ; 4.2 \%$ \\
Very strong & Animal with amputations and/or beheading after incidental capture & $\mathrm{n}=10 ; 5.2 \%$ \\
Strong & Animal with good body condition and no other defined cause of death & $\mathrm{n}=16 ; 8.3 \%$ \\
No evidence & Animal with death not related to fishing, such as predation and diseases & $\mathrm{n}=17 ; 8.8 \%$ \\
Indeterminate & Analysis made impossible by advanced decomposition & $\mathrm{n}=130 ; 67.7 \%$ \\
\hline
\end{tabular}


variation in the number of species and abundance of stranded turtles as a function of the length of the beach strip (m), the data was transformed into a log and analysed using Generalised Linear Models (GLM) in software R (R Core Team 2016).

\section{Results}

A total of 192 sea turtle strandings was recorded in the Municipalities of Rio das Ostras $(\mathrm{n}=104 ; 54.2 \%)$ and Macaé $(\mathrm{n}=88 ; 45.8 \%)$ between September 2017 to June 2019. Most stranded sea turtles were dead $(\mathrm{n}=182 ; 94.8 \%)$ and the majority part of their records were made through direct monitoring on the beaches $(\mathrm{n}=$ $126 ; 65.6 \%$ ). The indirect method, carried out by the population, registered $47 \%$ of strandings that occurred in the summer, between January and March $(\mathrm{n}=31)$.

Stranding records included green turtles, Chelonia mydas $(\mathrm{n}=151 ; 78.6 \%$ of the total), loggerheads, Caretta caretta $(\mathrm{n}=23 ; 12 \%)$, olive ridley turtle, Lepidochelys olivacea $(\mathrm{n}=14 ; 7.3 \%)$, leatherbacks, Dermochelys coriacea $(\mathrm{n}=2 ; 1 \%)$, hawksbill, Eretmochelys imbricata $(\mathrm{n}=1 ; 0.5 \%)$ and just one specimen $(\mathrm{n}=1 ; 0.5 \%)$ has not been identified due to the high degree of decomposition (Fig. 2A). The records of D. coriacea and E. imbricata were occasional and occurred only in the Municipality of Rio das Ostras.
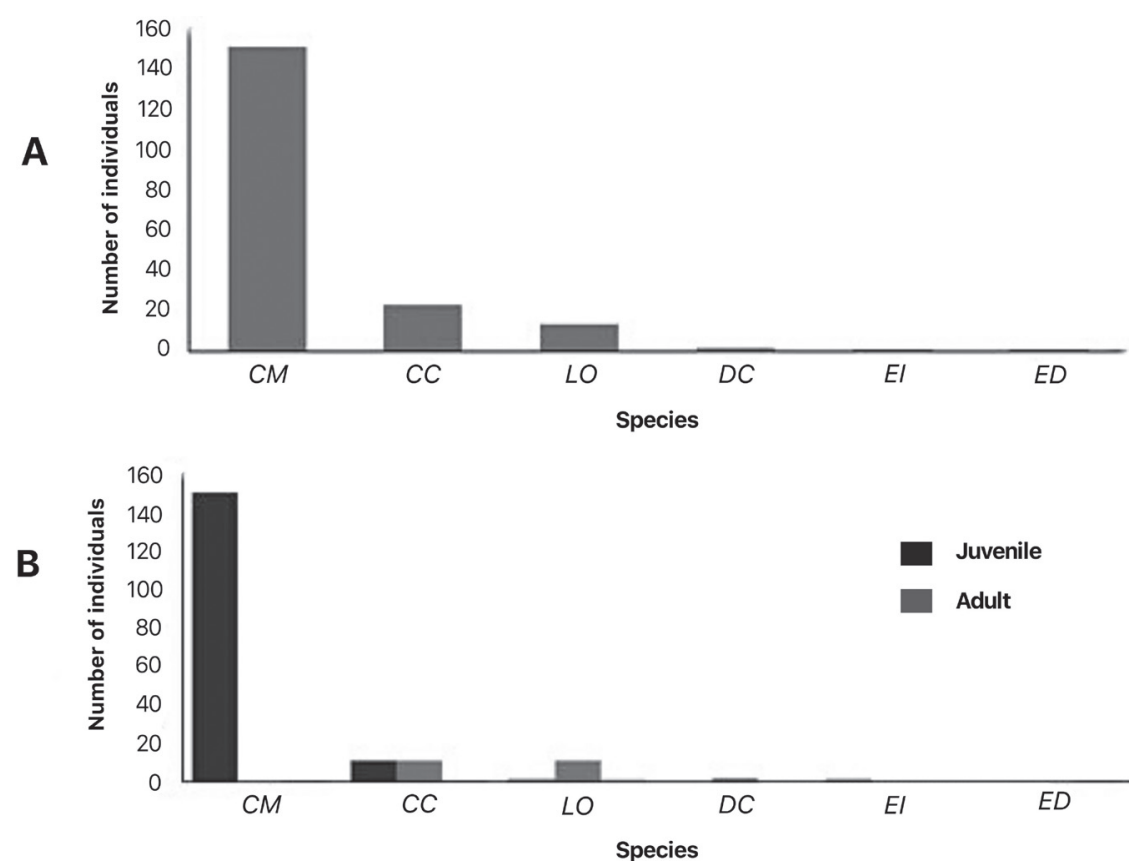

Figure 2. A. Total number of stranded individuals of the five species of sea turtles in Macaé and Rio das Ostras, north-central coast of the State of Rio de Janeiro, Brazil (2017-2019). B. Total number of individuals stranded in the juvenile and adult stages in each of the five species of sea turtles. $\mathrm{CM}=$ Chelonia mydas; $\mathrm{CC}=$ Caretta caretta $; \mathrm{LO}=$ Lepidochelys olivacea $; \mathrm{DC}=$ Dermochelys coriacea $; \mathrm{EI}=$ Eretmochelys imbricata; $\mathrm{ED}=$ undetermined species. 

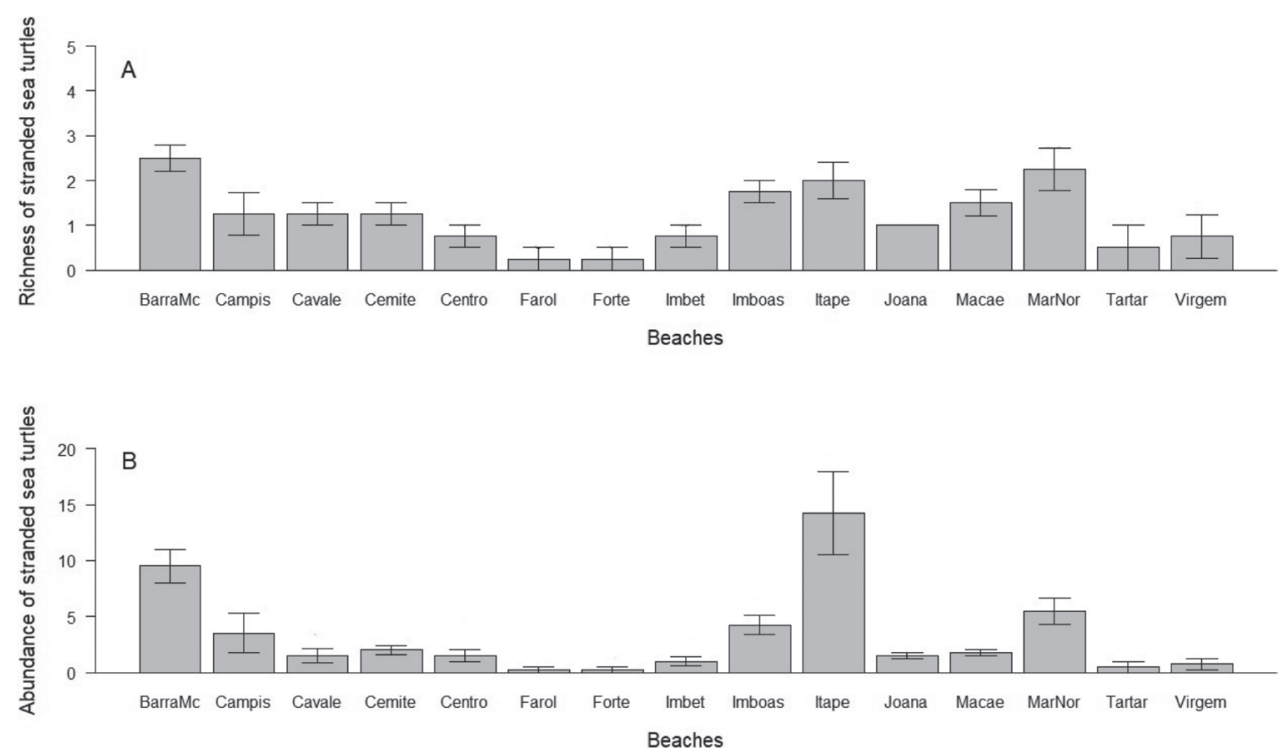

Figure 3. Average number of species (A) and abundance (B) of sea turtles stranded on the fifteen beaches sampled in the Municipalities of Macaé and Rios das Ostras, Rio de Janeiro, Brazil (20172019). Means followed by the same letter do not differ by Tukey's test $(P<0.05)$. Macaé beaches: Macaé, Barra de Macaé, Forte, Imbetiba, Farol, Cavaleiros, Campista and Imboassica. Rio das Ostras beaches: Tartaruga, Centro, Cemitério, Joana, Virgem, Mar do Norte and Itapebussus.

In C. mydas, $99.3 \%$ stranding records were of juvenile individuals $(\mathrm{n}=150)$. The number of stranded juveniles was close to that of adults in C. caretta $(\mathrm{n}=11 ; 47.8 \%)$, reduced in $L$. olivacea $(\mathrm{n}=1 ; 7.1 \%)$ and absent in $D$. coriacea. The only specimen sampled belonging to E. imbricata was a juvenile (Fig. 2B). Most stranded sea turtles were sampled in an advanced stage of decomposition (code $4 ; \mathrm{n}=114 ; 59.4 \%$ ), followed by the mummification stage (code $5 ; \mathrm{n}=47 ; 24.5 \%)$. Sex was defined in a few sampled individuals $(\mathrm{n}=32 ; 16.7 \%)$ and the majority were females (C. mydas, $\mathrm{n}=21 ;$ C. caretta, $\mathrm{n}=5 ;$ L. olivacea, $\mathrm{n}=1 ; D$. coriacea, $\mathrm{n}=1 ; 87.5 \%)$.

The abundance and number of species of stranded sea turtles varied between the sampled beaches (Fig. 3). Barra de Macaé beach showed the highest average number of sea turtle species stranded in the sampled months and the second highest abundance $(\mathrm{n}=38 ; 19.8 \%)$. Considering the total number of months sampled, the largest number of stranded species was observed on the Mar do Norte $(n=5)$, Itapebussus $(\mathrm{n}=4)$ and Barra de Macaé $(\mathrm{n}=3)$ beaches. The highest abundance was observed at Itapebussus Beach, $(\mathrm{n}=57 ; 29.7 \%)$ and it was where the highest number of passive monitoring occurred $(\mathrm{n}=29 ; 43.9 \%)$. On the most extensive beaches, the largest number of species and abundance of stranded sea turtles were recorded $\left(\mathrm{F}_{1 ; 13}=5.23 ; \mathrm{P}=0.03\right.$ and $\mathrm{F}_{1 ; 13}=19.65 ; \mathrm{P}<0.001$; respectively, Fig. 4).

The highest stranding record occurred in the summer $(\mathrm{n}=61 ; 31.8 \% ; 30.50 \pm$ $7.78)$ and in the spring $(\mathrm{n}=60 ; 31.2 \% ; 30.00 \pm 2.83)$ being February $(12.00 \pm 8.49)$ and October $(12.00 \pm 2.83)$, the months, on average, most sampled. However, there 
A

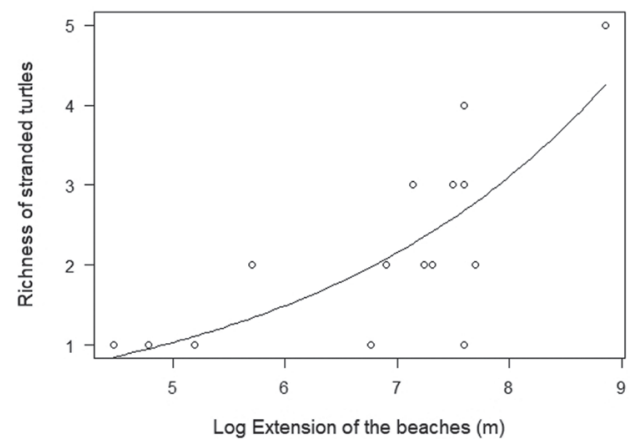

B

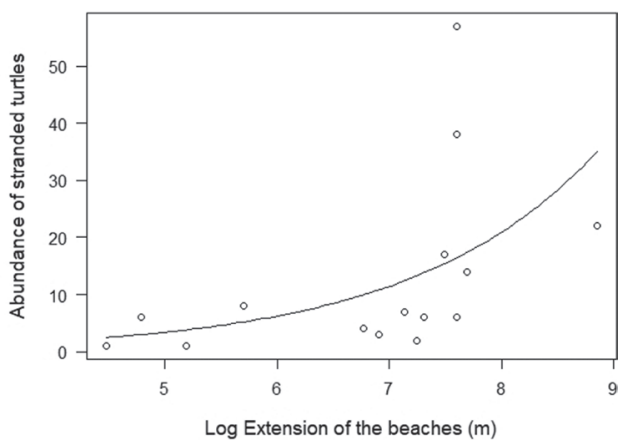

Figure 4. Relationship between number of species (A) and abundance (B) of stranded turtles with the extension of the beaches sampled in the Municipalities of Macaé and Rios das Ostras, Rio de Janeiro, Brazil (2017-2019).

was no significant variation between seasons (abundance: $\mathrm{F}_{3 ; 56}=0.85 ; P<0.47$ e and number of species: $\left.\mathrm{F}_{3: 56}=1.60 ; P=0.57\right)$.

The greatest occurrence of stranding was observed during the rainy season, between the months of October and March $(\mathrm{n}=121 ; 63 \%)$ and the most upwelling, between the months of October and April $(\mathrm{n}=133 ; 69.3 \%)$. In most records, climatic conditions indicated wind dominance in the northeast $(n=97 ; 50.5 \%)$ throughout the year, mainly in the summer $(\mathrm{n}=40 ; 41.2 \%$; Fig. 5$)$.

In the analysis of the degree of interaction of stranded organisms with fishing, the undetermined/unexamined category was predominant $(n=130 ; 67.7 \%)$. However, $8.3 \%$ were classified in the strong category $(n=16)$ and $5.2 \%$ in the very strong category $(n=10 ; 5.2 \%)$. Although less frequent, the category of total evidence, in which fishing gear is present on the animal's body, represented $4.2 \%$ of the records $(\mathrm{n}=8)($ Table 1$)$.

\section{Discussion}

The five species of sea turtles are found along the west coast of the South Atlantic, during their migrations or in population densities in specific regions, such as feeding areas or spawning sites (Bolten et al. 1998; Domingo et al. 2006; Marcovaldi et al. 2010; Vélez-Rubio et al. 2013; Tagliolatto et al. 2019a). On the coast of Brazil, aspects of biology and the analysis of the spatial and temporal distribution of stranded turtles have provided relevant data on the dynamics of populations, in addition to pointing out the main causes of threats (Marcovaldi and Marcovaldi 1999; Baptistotte et al. 2003; Thomé et al. 2007; Reis et al. 2009, 2010, 2017; Lima et al. 2010, 2012; Almeida et al. 2011; Awabdi et al. 2013; Goldberg et al. 2015; Lopes-Souza et al. 2015; Monteiro et al. 2016; Tagliolatto et al. 2019a).

In literature studies, sea turtle stranding records apply stretches with different variations and/or sampling statistics and types of monitoring, which reflect different 

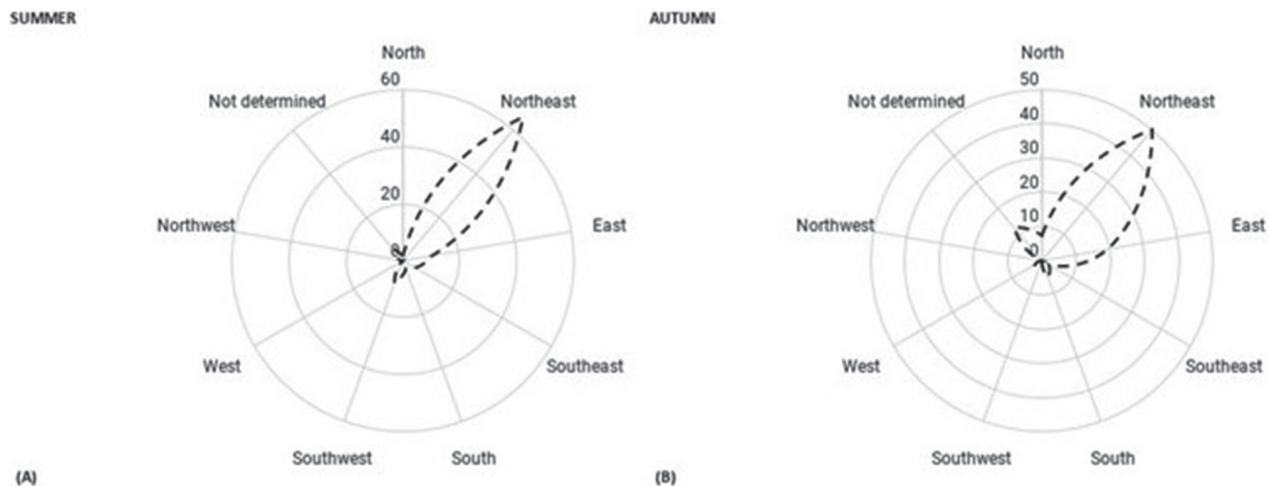

WINTER

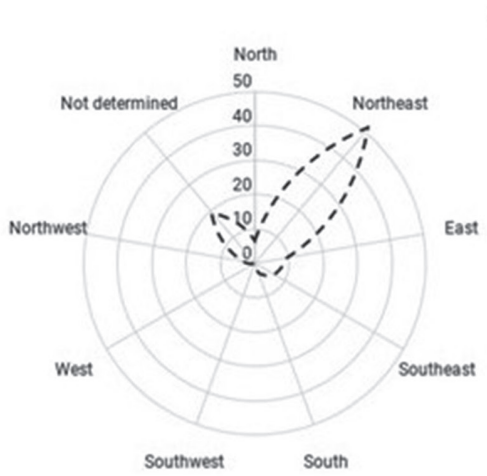

SPRING

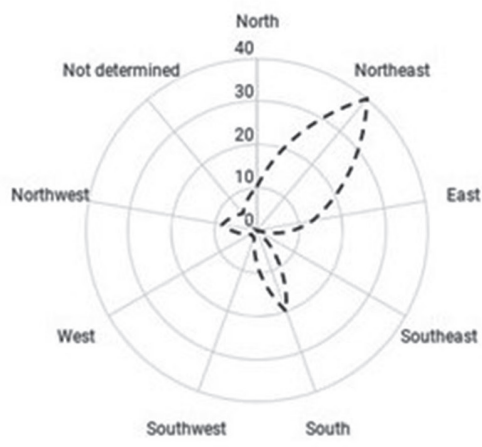

(c)

Figure 5. Frequency of wind direction in the four different seasons: summer (A), autumn (B), winter (C) and spring (D) in Rio das Ostras and Macaé, Rio de Janeiro, Brazil (2017 to 201). ${ }^{\star}$ Not determined refers to cases in which it was not possible to determine the wind direction.

patterns regarding the number of species and abundance of stranded individuals, also associated with feeding areas and spawning of the group (Table 2). Tagliolatto et al. (2019a), in a comprehensive analysis of sea turtles stranding on the coast of the Rio de Janeiro State, with 1,317 km, registered 12,162 individuals, of these, 11,087 were in the central-northern stretch of the coast, in six years of active and passive daily monitoring (2010-2016). Reis et al. (2009) analysed approximately $247 \mathrm{~km}$ along the central-north axis of the coast and recorded 57 stranded turtles over ten years through active and passive monitoring (1994-2004); however, a single sampling with active monitoring was carried out each summer. In the same centralnorth axis, for two years (2009-2010), a greater length of the coast was sampled, approximately $290 \mathrm{~km}$, using a continuous sampling method and active and passive monitoring during which 3,050 sea turtle stranding were recorded (Reis et al. 2017). However, amongst the 12 sampled Municipalities, Rio das Ostras and Macaé had a reduced number of stranded turtles ( $\mathrm{n}=4$ and 9, respectively). In this study, 192 stranding of sea turtles were recorded during two years along approximately $24 \mathrm{~km}$ of beaches, with the strandings' abundance in this period being much higher than 
Table 2. Data recording of sea turtle stranding on the west coast of the South Atlantic. For each reference, the time (months), the distance covered, the type of sampling (active/passive), the wealth and abundance of individuals observed and the average value of individuals collected per month of sampling are provided. The geographical location of the study area of the works cited is indicated on the map in Figure 1 with the reference number.

\begin{tabular}{|c|c|c|c|c|c|c|}
\hline Study location & $\begin{array}{l}\text { Sampling time } \\
\text { (months) }\end{array}$ & $\begin{array}{l}\text { Sampled beach } \\
\text { extension }(\mathbf{k m})\end{array}$ & $\begin{array}{l}\text { Monitoring } \\
\text { type (active/ } \\
\text { passive) }\end{array}$ & $\begin{array}{l}\text { Species richness } \\
\text { and abundance } \\
\text { of individuals }\end{array}$ & $\begin{array}{c}\text { Number of } \\
\text { stranded } \\
\text { individuals / } \\
\text { months }\end{array}$ & References \\
\hline 01. Coast of Uruguay & $144(1999-2010)$ & 710 & active/passive & $5-1107$ & 10.64 & Vélez-Rubio et al. (2013) \\
\hline 02. Rio Grande do Sul - Brazil & $12(1997-1998)$ & 720 & active & $3-92$ & 7.66 & Bugoni et al. (2001) \\
\hline 03. Rio Grande do Sul - Brazil & $118(1995-2004)$ & 620 & active & $4-994$ & 8.42 & Monteiro (2004) \\
\hline 04. Rio Grande do Sul - Brazil & $39(2007-2010)$ & 120 & active & $3-640$ & 16.41 & Scherer et al. (2014) \\
\hline 05. Santa Catarina - Brazil & $10(2011-2012)$ & 37.5 & active & $2-15$ & 1.5 & Luzzietti (2013) \\
\hline 06. Santa Catarina - Brazil & $25(2015-2017)$ & - & active & $4-503$ & 20.12 & Santos (2019) \\
\hline 07. Paraná - Brazil & $37(2004-2007)$ & 600 & active & $1-80$ & 2.16 & $\begin{array}{l}\text { Guebert-Bartholo et al. } \\
\qquad(2011)\end{array}$ \\
\hline 08. São Paulo - Brazil & $13(2016-2017)$ & 30 & active & $1-15$ & 1.15 & Edris et al. (2018) \\
\hline 09. Rio de Janeiro - Brazil & $132(1994-2004)$ & 248 & active/passive & $5-57$ & 0.43 & Reis et al. (2009) \\
\hline 10. Rio de Janeiro - Brazil & $12(2009)$ & 248 & active/passive & $5-143$ & 11.91 & Reis et al. (2010) \\
\hline 11. Rio de Janeiro - Brazil & $12(2011)$ & 71 & active & $5-23$ & 1.91 & De Carvalho et al. (2015) \\
\hline 12. Rio de Janeiro - Brazil & $24(2008-2010)$ & 290 & active/passive & $5-3050$ & 127.08 & Reis et al. (2017) \\
\hline 13. Rio de Janeiro - Brazil & $13(2016-2017)$ & 985 & active/passive & $5-1138$ & 87.53 & Werneck et al. (2018) \\
\hline 14. Rio de Janeiro - Brazil & $91(2010-2017)$ & 1317 & active/passive & $5-12162$ & 133.64 & Tagliolatto et al. (2019a) \\
\hline 15. Espírito Santo- Brazil & $72(2007-2012)$ & 24 & active & $5-1154$ & 16.02 & Berrêdo et al. (2013) \\
\hline 16. Bahia - Brazil & $30(2006-2008)$ & 270 & active/passive & $4-260$ & 8.66 & Coelho (2009) \\
\hline 17. Bahia - Brazil & $30(2006-2008)$ & 220 & active/passive & $4-260$ & 8.66 & Lopes-Souza et al. (2015) \\
\hline 18. Paraíba - Brazil & $12(2002-2003)$ & 130 & active/passive & $3-70$ & 5.83 & Mascarenhas et al. (2005) \\
\hline 19. Paraíba- Brazil & $12(2009-2010)$ & 15 & active/passive & $4-124$ & 10.33 & Poli et al. 2014 \\
\hline 20. Ceará - Brazil & $23(2005-2006)$ & - & active & $5-86$ & 3.73 & Lima et al. (2010) \\
\hline $\begin{array}{l}\text { 21. Ceará-Rio Grande do } \\
\text { Norte - Brazil }\end{array}$ & $36(2010-2013)$ & 332.84 & active & $5-2658$ & 73.83 & Farias (2015) \\
\hline
\end{tabular}

that found in other sampling intervals. The high abundance of stranding, compared to other studies in the region, can be attributed to the daily, continuous sampling effort, the use of direct and indirect monitoring and the possible increase in human activities that can interfere and threaten the life cycle of the turtles.

Stranded sea turtles are commonly found dead at the various points already sampled along the South Atlantic coast (Reis et al. 2009, 2017; Vélez-Rubio et al. 2013; González-Carman et al. 2014; Poli et al. 2014; Lopez-Souza et al. 2015; Tagliolatto et al. 2019a). The large number of juveniles in an advanced state of decomposition indicates the large time interval between death and stranding, being an indication that they are suffering severe threats in the marine ecosystem, accelerating the decline in population densities (Guebert et al. 2013; Carvalho et al. 2016). The area sampled in the present study is one of the oil explorations zones in Brazil, with intense on- and offshore activities, which generate high traffic of vessels.

Most strandings were recorded through active monitoring on the beaches, which shows its efficiency in inventorying stranded fauna data, as well as the rapid transport of dead animals or veterinary care to debilitated organisms (Meirelles et al. 2009; Velozo et al. 2009; Guebert-Bartholo et al. 2011; Lopez-Souza et al. 2015). 
The passive monitoring method, triggered by the population, was observed mainly during the summer, months that coincide with holidays in Brazil and, therefore, the flow of tourists on the beaches and the intensity of the awareness campaigns are greater (Batista et al. 2012; Lopes-Souza et al. 2015).

In the north-central region of the coast of Rio de Janeiro State, there is a phenomenon of upwelling in the estuarine regions that increase the supply of food resources, making it a possible feeding area for the five species of sea turtles registered for Brazil (Valentin 2001; Amorocho and Reina 2007; Reis et al. 2017; Tagliolatto et al. 2019a). In this region, a green turtle, C. mydas exhibited, in all samples, a large number of stranding, a majority in the juvenile stage (Reis et al. 2009, 2017; Tagliolatto et al. 2019a). This pattern was also found in other regions of the South Atlantic where rocky shores appear in coastal areas (Mascarenhas et al. 2005) forming large banks of algae, the main food resource in the juvenile stage (Santos et al. 2011; Lopes-Souza et al. 2015; Awabdi et al. 2013). As adults, green turtles migrate to reproduce and spawn on oceanic islands such as Trindade, Fernando de Noronha and Atol das Rocas (Bellini et al. 2013).

The loggerhead turtle, C. caretta, was the second most frequent species in stranding, with a similar number of individuals in the juvenile and adult stages. About $100 \mathrm{~km}$ north of the area sampled in this study is located the second largest spawning site of the loggerhead turtle in Brazil (Marcovaldi et al. 2011; Santos et al. 2011; Reis et al. 2017); therefore, the records can be from individuals on their migration routes to nesting sites and/or feeding areas. In some regions of the North Atlantic, the loggerhead turtle had the highest stranding frequency, such as on the coast of Portugal (Nicolau et al. 2016) and Mexico (Koch et al. 2013).

As found in this study, the species, L. olivacea, E. imbricata and D. coriacea, have been little registered on the Rio de Janeiro coast, a region that is not considered a usual spawning site for any of them. In addition, these species prefer reefs and ocean habitats closer to their nesting areas to forage (Reis et al. 2009, 2017; Tagliolatto et al. 2019a). Thus, the low abundance recorded, probably, involves individuals on their migratory routes to nesting sites or feeding areas.

For sea turtles, the measurement of the curvilinear carapace length (CCL) is one of the criteria used to define the stage of specimens' development. During the juvenile stage, sea turtles do not have sexual dimorphism, based on external characters, which made it impossible to define sex in most individuals. In cases where sexing was possible, the majority were females, as also registered for the coast of Bahia State (Lopes-Souza et al. 2015).

On larger beaches, greater numbers of strandings and species were observed. Most stranded turtles were in an advanced stage of decomposition, which indicates that they could have died days ago and were adrift in the sea. Physical oceanographic events, involving sea currents and wind direction, can determine the locations of strand registration (Epperly et al. 1996; Santos 2019), which would possibly be a random event in the stretch sampled in the present study $(23.8 \mathrm{~km})$. The relationship between the length of the beaches and the number of stranding records 
could indicate some point of greatest anthropogenic threat, if this relationship were inversely proportional. One of the beaches with the highest records number was the Itapebussus Beach, in addition to being extensively recorded on a large scale by passive monitoring. This Itapebussus Beach is not urbanised and is inserted in a protected conservation area of relevant ecological interest, which makes it attractive to a large number of tourists who contribute to the report of strandings.

The relationship of the greatest stranding number on more extensive beaches may indicate a random effect on the individuals dragging, with greater chances of stranding on more extensive beaches. However, the factors that determine stranding locations involve the effects of wind direction and speed, ocean currents and topographic characteristics of the coastal zone (Tagliolatto et al. 2019a). Wind influences surface marine currents, performing a relevant role in directing stranded animals through Ekman transport (Epperly et al. 1996; Meager and Limpus 2012; Tonolli 2013).

Seasonality did not show a significant relationship with the richness and abundance of sea turtle stranding; however, the largest records number occurred in summer and spring, as observed in other coastal regions of Brazil (Poli et al. 2014; Lopes-Souza et al. 2015). During these seasons, sea turtles migrate to the coast to complete their reproductive periods and nest on the beaches (Camillo et al. 2009). In addition, in the summer there is wind dominance in the northeast direction that can direct turtles or their carcasses towards the beaches (Dominguez et al. 1992; Bittencourt et al. 2007; Tonolli 2013; Lopes-Souza et al. 2015), in addition to the large increase in the frequency of passive monitoring, triggered by the population.

Amongst the various anthropogenic activities that directly impact the life cycle and survival of sea turtles, fishing activities and marine debris are identified as one of the main threats (Marcovaldi et al. 2006; López-Barrera et al. 2012; BarriosGarrido and Montiel-Villalobos 2016; Nicolau et al. 2016; Domiciano et al. 2017; Guimarães et al. 2018; Santos et al. 2018; Silva et al. 2018; Tagliolatto et al. 2019b). About $18 \%$ of the individuals, registered in this study, had some degree of relationship with fishing activities (Table 1). However, the direct association of stranding or mortality with fishing was hampered due to the advanced decomposition stage, which can cause traces loss, such as fishing gear or their marks and injuries caused to the animal (Nicolau et al. 2016). Tagliolatto et al. (2019a) pointed out recently 33 stranding records in the Rio das Ostras and Macaé Municipalities with characteristics that were associated with mortality factors related to fishing activities.

\section{Conclusions}

The north-central coast of the Rio de Janeiro State has intense fishing activity, oil exploration activities that generate impacts with vessels and dredging and large population densities that can contribute to the increase in oceanic debris (Tagliolatto et al. 2019a). These anthropogenic threats can be factors that contributed to the number of sea turtle stranding recorded in this work. Long-term studies in Brazil point 
to fishing as one of the main threats and suggest management plans that involve seasons with high numbers of strandings, such as spring and summer (Monteiro et al. 2016). The studies involving strandings of turtles point to a considerable increase in the last decade and point to the importance of intensifying studies on the stranding causes and the dissemination of measures that can mitigate the impacts on the entire dynamics of the marine ecosystem.

\section{References}

Almeida AP, Moreira LM, Bruno SC, Thomé JCA, Martins AS, Bolten AB, Bjorndal KA (2011) Green turtle nesting on Trindade Island, Brazil: Abundance, trends, and biometrics. Endangered Species Research 14(3): 193-201. https://doi.org/10.3354/esr00357

Amorocho DF, Reina RD (2007) Feeding ecology of the East Pacific green sea turtle Chelonia mydas agassizii at Gorgona National Park, Colombia. Endangered Species Research 3(1): 43-51. https://doi.org/10.3354/esr003043

Awabdi DR, Siciliano S, Di Beneditto APM (2013) First information about the stomach contents of juvenile green turtles, Chelonia mydas, in Rio de Janeiro, south-eastern Brazil. Marine Biodiversity Records 6: 1-6. https://doi.org/10.1017/S1755267212001029

Baptistotte C, Thomé JCA, Bjorndal KA (2003) Reproductive biology and conservation status of the loggerhead sea turtle (Caretta caretta) in Espírito Santo State, Brazil. Chelonian Conservation and Biology 4(3): 523-529.

Barrios-Garrido H, Montiel-Villalobos MG (2016) Strandings of Leatherback turtles (Dermochelys coriacea) along the western and southern coast of the Gulf of Venezuela. Herpetological Conservation and Biology 11: 244-252.

Batista RLG, Schiavetti A, Santos UAD, Reis MSS (2012) Cetaceans registered on the coast of Ilhéus (Bahia), northeastern Brazil. Biota Neotropica 12(1): 31-38. https://doi. org/10.1590/S1676-06032012000100003

Bellini C, Santos AJ, Grossman A, Marcovaldi MA, Barata PC (2013) Green turtle (Chelonia mydas) nesting on Atol das Rocas, north-eastern Brazil, 1990-2008. Journal of the Marine Biological Association of the United Kingdom 93(4): 1117-1132. https://doi. org/10.1017/S002531541200046X

Berrêdo R, Rosa M, Giffoni B, Sales G, Britto M, Thomé J, Leite Jr N (2013) Encalhes e interação da pesca costeira com tartarugas marinhas em Anchieta, Espírito Santo, Brasil. VI Jornada y VII Reunión De Conservación E Investigación De Tortugas Marinas en el Atlántico Sur Occidental (ASO), 59-64.

Bittencourt AC, Dominguez JM, Martin L, Silva IR, Medeiros KO (2007) Past and current sediment dispersion pattern estimates through numerical modeling of wave climate: An example of the Holocene delta of the Doce River, Espírito Santo, Brazil. Anais da Academia Brasileira de Ciências 79(2):333-341. https://doi.org/10.1590/S0001-37652007000200014 Bolten AB, Bjorndal KA, Martins HR, Dellinger T, Biscoito MJ, Encalada SE, Bowen BW (1998) Transatlantic developmental migrations of loggerhead sea turtles demonstrated by mtDNA sequence analysis. Ecological Applications 8(1): 1-7. https://doi. org/10.1890/1051-0761(1998)008[0001:TDMOLS]2.0.CO;2 
Bugoni L, Krause L, Petry MV (2001) Marine debris and human impacts on sea turtles in Southern Brazil. Marine Pollution Bulletin 42(12): 1330-1334. https://doi.org/10.1016/ S0025-326X(01)00147-3

Camillo CS, Romero RDM, Leone LG, Batista RLG, Velozo RS, Nogueira-Filho SLG (2009) Características da reprodução de tartarugas marinhas (Testudines, Cheloniidae) no litoral sul da Bahia, Brasil. Biota Neotropica 9(2): 131-137. https://doi.org/10.1590/ S1676-06032009000200013

Carvalho RH, Lacerda PD, Silva MS, Barbosa BC, Paschoalini M, Prezoto F, Sousa BM (2015) Marine debris ingestion by sea turtles (Testudines) on the Brazilian coast: An underestimated threat? Marine Pollution Bulletin 101(2): 746-749. https://doi.org/10.1016/j. marpolbul.2015.10.002

Carvalho RH, Mamede N, Bastos RR, Sousa BM (2016) Attitudes towards conservation and fishing interaction with sea turtles in the southeast coast of Brazil. Ocean and Coastal Management 127: 55-62. https://doi.org/10.1016/j.ocecoaman.2016.04.011

Castilhos JC, Coelho CA, Argolo JF, Santos EAP, Marcovaldi MA, Santos AS, Lopez M (2011) Avaliação do estado de conservação da tartaruga marinha Lepidochelys olivacea (Eschscholtz, 1829) no Brasil. Biodiversidade Brasileira 1: 28-36.

Coelho BB (2009) Análise dos encalhes de tartarugas marinhas (Reptilia: Testudines), ocorridos no litoral sul da Bahia, Brasil. Dissertação de Mestrado, Programa de Pós-graduação em Zoologia, Universidade Estadual de Santa Cruz, Bahia.

Domiciano IG, Domit C, Bracarense APFRL (2017) The green turtle Chelonia mydas as a marine and coastal environmental sentinel: Anthropogenic activities and diseases. Semina. Ciências Agrárias 38(5): 417-3434. https://doi.org/10.5433/1679-0359.2017v38n5p3417

Domingo A, Bugoni L, Prosdocimi L, Miller P, Laporta M, Monteiro DS, Albareda D (2006) The impact generated by fisheries on sea turtles in the southwestern Atlantic. WWF Programa Marino para Latinoamérica y el Caribe, San José, 70 pp.

Dominguez JL, Bittencourt ACSP, Martín L (1992) Controls on Quaternary coastal evolution of the east-northeastern coast of Brazil: Roles of sea-level history, trade winds and climate. Sedimentary Geology 80(3-4): 213-232. https://doi.org/10.1016/0037-0738(92)90042-P Edris QL, Leite CS, Silva CSA, Melo LF, Fanelli C (2018) Análise do conteúdo alimentar de tartarugas-verdes (Chelonia mydas) mortas em encalhes na Costa de Peruíbe, litoral Sul de São Paulo. Unisanta BioScience 7(6): 77-98.

Epperly SP, Braun J, Chester AJ, Cross FA, Merriner JV, Tester PA, Churchill JH (1996) Beach strandings as an indicator of at-sea mortality of sea turtles. Bulletin of Marine Science 59(2): 289-297.

Farias DSDD (2015) Padrões espaciais e temporais do encalhe de tartarugas marinhas no nordeste do Brasil: diagnóstico e ameaças. Trabalho de Conclusão de Curso. Universidade Federal do Rio Grande do Norte, Rio Grande do Norte, Brasil.

Geraci JR, Lounsbury VJ (2005) Marine mammals ashore: a field guide for strandings. National Aquarium in Baltimore. Texas A \& M University, Texas, $371 \mathrm{pp}$.

Goldberg DW, Almeida DT, Tognin F, Lopez GG, Pizetta GT, Leite-Junior NDO, Sforza R (2015) Hopper dredging impacts on sea turtles on the northern coast of Rio de Janeiro State, Brazil. Marine Turtle Newsletter 147: 16-20. 
González-Carman V, Botto F, Gaitán E, Albareda D, Campagna C, Mianzan H (2014) A jellyfish diet for the herbivorous green turtle Chelonia mydas in the temperate SW Atlantic. Marine Biology 161(2): 339-349. https://doi.org/10.1007/s00227-013-2339-9

Guebert FM, Barletta M, Costa MF (2013) Threats to sea turtle populations in the Western Atlantic: Poaching and mortality in small-scale fishery gears. Journal of Coastal Research 65: 42-47. https://doi.org/10.2112/SI65-008.1

Guebert-Bartholo FM, Barletta M, Costa MF, Monteiro-Filho ELA (2011) Using gut contents to assess foraging patterns of juvenile green turtles Chelonia mydas in the Paranaguá Estuary, Brazil. Endangered Species Research 13(2): 131-143. https://doi.org/10.3354/esr00320

Guimarães SM, Tavares DC, Monteiro-Neto C (2018) Incidental capture of sea turtles by industrial bottom trawl fishery in the Tropical South-western Atlantic. Journal of the Marine Biological Association of the United Kingdom 8(6): 1525-1531. https://doi. org/10.1017/S0025315417000352

IBGE (2020) Instituto Brasileiro de Geografia e Estatística (IBGE). Censo Brasileiro de 2020. Brasil, IBGE, Rio de Janeiro, 2012.

ICMBio/MMA (2018) Chico Mendes Institute for Biodiversity Conservation/Ministry of Environment. Livro Vermelho da Fauna Brasileira Ameaçada de Extinção: Volume IV - Répteis. In: Instituto Chico Mendes de Conservação da Biodiversidade (Orgs) Livro Vermelho da Fauna Brasileira Ameaçada de Extinção. ICMBio, Brasília, 45-47.

IUCN (2021) The IUCN Red List of Threatened Species. Version 2021.2. http://ww.iucnredlist. org [last access in 20/08/2021]

Kannan P (2008) Studies on the green turtle (Chelonia mydas) in the Gulf of Mannar biosphere reserve, Tamil Nadu, India. Indian Ocean Turtle Newsletter 7: 12-15.

Koch V, Peckham H, Mancini A, Eguchi T (2013) Estimating at-sea mortality of marine turtles from stranding frequencies and drifter experiments. PLoS ONE 8(2): e56776. https://doi.org/10.1371/journal.pone.0056776

Kotas JE, Santos S, Azevedo VG, Gallo BM (2004) Incidental capture of loggerhead (Caretta caretta) and leatherback (Dermochelys coriacea) sea turtles by the pelagic longline fishery off southern Brazil. Fish Bulletin 102(2): 393-399. http://fishbull.noaa.gov/1022/kotas.pdf

Lima EHSM, Melo MTD, Barata PCR (2010) Incidental capture of sea turtles by the lobster fishery off the Ceará Coast, Brazil. Marine Turtle Newsletter 128: 16-19.

Lima EPE, Wanderlinde J, Almeida DT, Lopez GG, Goldberg DW (2012) Nesting ecology and conservation of the loggerhead sea turtle (Caretta caretta) in Rio de Janeiro, Brazil. Chelonian Conservation and Biology 11(2): 249-254. https://doi.org/10.2744/CCB-0996.1

Lopes-Souza A, Schiavetti A, Álvarez MR (2015) Analysis of marine turtle strandings (Reptilia: Testudine) occurring on coast of Bahia State, Brazil. Latin American Journal of Aquatic Research 43(4): 675-683. https://doi.org/10.3856/vol43-issue4-fulltext-6

López-Barrera EA, Longo GO, Monteiro-Filho ELA (2012) Incidental capture of green turtle (Chelonia mydas) in gillnets of small-scale fisheries in the Paranaguá Bay, Southern Brazil. Ocean and Coastal Management 60: 11-18. https://doi.org/10.1016/j.ocecoaman.2011.12.023

López-Mendilaharsu M, Rocha CF, Miller P, Domingo A, Prosdocimi L (2009) Insights on leatherback turtle movements and high use areas in the Southwest Atlantic Ocean. 
Journal of Experimental Marine Biology and Ecology 378(1-2): 31-39. https://doi. org/10.1016/j.jembe.2009.07.010

López-Mendilaharsu M, Giffoni B, Monteiro D, Prosdocimi L, Vélez-Rubio GM, Fallabrino A, Estrades A, Santos AS, Lara PH, Pires T, Tiwari T, Bolten AB, Marcovaldi MA (2020) Multiple-threats analysis for loggerhead sea turtles in the southwest Atlantic Ocean. Endangered Species Research 41: 183-196. https://doi.org/10.3354/esr01025

Luzzietti JR (2013) Análise dos encalhes de tartarugas marinhas ocorridos no litoral do município de Jaguaruna, Santa Catarina, Brasil. Trabalho de Conclusão de Curso. Universidade do Extremo Sul Catarinense, Jaguaruna.

Macêdo GR, Tarantino TB, Barbosa IS, Pires TT, Rostan G, Goldberg DW, Pinto LFB, Korn MGA, Franke CR (2015) Trace elements distribution in hawksbill turtle (Eretmochelys imbricata) and green turtle (Chelonia mydas) tissues on the northern coast of Bahia, Brazil. Marine Pollution Bulletin 94: 284-289. https://doi.org/10.1016/j.marpolbul.2015.02.033

Marcovaldi MA, Chaloupka M (2007) Conservation status of the loggerhead sea turtle in Brazil: An encouraging outlook. Endangered Species Research 3(2): 133-143. https:// doi.org/10.3354/esr003133

Marcovaldi MA, Freitas O (2000) Assim nasceu o projeto Tamar. Fundação Pró-Tamar, Salvador. Marcovaldi MA, Marcovaldi GG (1999) Marine turtles of Brazil: The history and structure of Projeto TAMAR-IBAMA. Biological Conservation 91(1): 35-41. https://doi. org/10.1016/S0006-3207(99)00043-9

Marcovaldi MA, Sales G, Thomé JC, Silva ACCD, Gallo BM, Lima EHSM, Lima EP, Bellini C (2006) Sea turtles and fishery interactions in Brazil: Identifying and mitigating potential conflicts. Marine Turtle Newsletter 112(1): 4-8.

Marcovaldi MA, Lopez GG, Soares LS, Lima EHSM, Thomé JCA, Almeida AP (2010) Satellite-tracking of female loggerhead turtles highlights fidelity behavior in northeastern Brazil. Endangered Species Research 12(3): 263-272. https://doi.org/10.3354/esr00308

Marcovaldi MA, Santos AS, Sales G (2011) Plano de Ação Nacional para Conservação das Tartarugas Marinhas. ICMBio, Brasília, 63 pp.

Mascarenhas R, Santos R, Zeppelini D (2005) Stranded sea turtles on the coast of Paraíba, Brazil. Marine Turtle Newsletter 107: 13-14.

Meager JJ, Limpus CJ (2012) Marine wildlife stranding and mortality database annual report 2011. III. Marine Turtle. Conservation Technical and Data Report 3: 1-46.

Meirelles ACO, Monteiro-Neto C, Martins AM, Costa AF, Barros HM, Alves MDO (2009) Cetacean strandings on the coast of Ceará, northeastern Brazil (1992-2005). Journal of the Marine Biological Association 89(5): 1083-1090. https://doi.org/10.1017/ S0025315409002215

Monteiro DS (2004) Encalhes e interação de tartarugas marinhas com a pesca no litoral do Rio Grande do Sul. Monografia (Graduação em Biologia). Universidade Federal do Rio Grande do Sul, Porto Alegre.

Monteiro DS, Estima SC, Gandra TB, Silva AP, Bugoni L, Swimmer Y, Seminoff J, Secchi ER (2016) Long-term spatial and temporal patterns of sea turtle strandings in southern Brazil. Marine Biology 163(12): 1-19. https://doi.org/10.1007/s00227-016-3018-4 
Nicolau L, Ferreira M, Santos J, Araújo H, Sequeira M, Vingada J, Marçalo A (2016) Sea turtle strandings along the Portuguese mainland coast: Spatio-temporal occurrence and main threats. Marine Biology 163(1): e21. https://doi.org/10.1007/s00227-015-2783-9

Poli C, Lopez LCS, Mesquita DO, Saska C, Mascarenhas R (2014) Patterns and inferred processes associated with sea turtle strandings in Paraíba State, northeast Brazil. Brazilian Journal of Biology 74(2): 283-289. https://doi.org/10.1590/1519-6984.13112

Pupo MM, Soto JMR, Hanazaki N (2006) Captura incidental de tartarugas marinhas na pesca rtesanal da Ilha de Santa Catarina, SC. Biotemas 19(4): 63-72.

R Core Team (2016) R: A Language and Environment for Statistical Computing. R Foundation for Statistical Computing, Vienna. https://www.R-project.org/

Reis EC, Silveira VVB, Siciliano S (2009) Records of stranded sea turtles on the coast of Rio de Janeiro State, Brazil. Marine Biodiversity Records 2: 1-4. https://doi.org/10.1017/ S1755267209001262

Reis EC, Pereira CS, Rodrigues DDP, Secco HKC, Lima LM, Rennó B, Siciliano S (2010) Condição de saúde das tartarugas marinhas do litoral centro-norte do estado do Rio de Janeiro, Brasil: Avaliação sobre a presença de agentes bacterianos, fibropapilomatose e interação com resíduos antropogênicos. Oecologia Australis 14(03): 756-765. https:// doi.org/10.4257/oeco.2010.1403.11

Reis EC, Goldberg DW, Lopez GG (2017) Diversidade e distribuição de tartarugas marinhas na área de influência das atividades de E\&P na Bacia de Campos. Mamíferos, quelônios e aves: caracterização ambiental regional da Bacia de Campos, Atlântico Sudoeste. Elsevier 7: 121-159. https://doi.org/10.1016/B978-85-352-7661-9.50006-3

Santos CD (2019) Análise dos encalhes de tartarugas marinhas no litoral leste da Ilha de Santa Catarina, Brasil. Trabalho de Conclusão de Curso. Universidade Federal de Santa Catarina, Florianópolis.

Santos RG, Martins AS, Farias JN, Horta PA, Pinheiro HT, Torezani E, Baptistotte C, Seminoff JA, Balazs GH, Work TM (2011) Coastal habitat degradation and green sea turtle diets in Southeastern Brazil. Marine Pollution Bulletin 62(6): 1297-1302. https://doi. org/10.1016/j.marpolbul.2011.03.004

Santos BS, Friedrichs MA, Rose SA, Barco SG, Kaplan DM (2018) Likely locations of sea turtle stranding mortality using experimentally-calibrated, time and space-specific drift models. Biological Conservation 226: 127-143. https://doi.org/10.1016/j.biocon.2018.06.029

Senko J, Mancini A, Seminoff JA, Koch V (2014) Bycatch and directed harvest drive high green turtle mortality at Baja California Sur, Mexico. Biological Conservation 169: 2430. https://doi.org/10.1016/j.biocon.2013.10.017

Scherer AS, Valls FCL, Basler AB, Scherer JFM, Petry MV (2014) Life stages, anthropogenic impact, and temporal variation of stranded sea turtles in southern Brazil. Chelonian Conservation and Biology 13(1): 42-48. https://doi.org/10.2744/CCB-1029.1

Silva ACCD, Castilhos JC, Lopez GG, Barata PCR (2007) Nesting biology and conservation of the olive ridley sea turtle (Lepidochelys olivacea) in Brazil, 1991/1992 to 2002/2003. Journal of the Marine Biological Association of the United Kingdom 87(4): 1047-1056. https://doi.org/10.1017/S0025315407056378 
Silva ML, Castro RO, Sales AS, Araújo FV (2018) Marine debris on beaches of Arraial do

Cabo, RJ, Brazil: An important coastal tourist destination. Marine Pollution Bulletin 130: 153-158. https://doi.org/10.1016/j.marpolbul.2018.03.026

Tagliolatto AB, Goldberg DW, Godfrey MH, Monteiro-Neto C (2019a) Spatio-temporal distribution of sea turtle strandings and factors contributing to their mortality in southeastern Brazil. Aquatic Conservation 30(2): 331-350. https://doi.org/10.1002/aqc.3244

Tagliolatto AB, Giffoni B, Guimarães S, Godfrey MH, Monteiro-Neto C (2019b) Incidental capture and mortality of sea turtles in the industrial double-rig-bottom trawl fishery in south-eastern. Aquatic Conservation 30(2): 351-363. https://doi.org/10.1002/aqc.3252

Thomé JC, Baptistotte C, Moreira LMP, Scalfoni JT, Almeida AP, Rieth DB, Barata PCR (2007) Nesting biology and conservation of the leatherback sea turtle (Dermochelys coriacea) in the State of Espírito Santo, Brazil. Chelonian Conservation and Biology 6(1): 15-27. https://doi.org/10.2744/1071-8443(2007)6[15:NBACOT]2.0.CO;2

Tonolli FAS (2013) Tendências de encalhes de toninhas, Pontoporia Blainvillei, no litoral norte do Rio Grande do Sul, Brasil (1991-2005): avaliando a influência das capturas acidentais e de fatores ambientais. Dissertação de Mestrado-Programa de Pós-graduação em Zoologia. Universidade Estadual de Santa Cruz, Santa Cruz, Bahia.

Valentin JL (2001) The Cabo Frio upwelling system, Brazil. In: Seeliger U, Kjerfve B (Eds) Coastal Marine Ecosystems of Latin America. Ecological Studies (Analysis and Synthesis), vol. 144. Springer, Berlin, Heidelberg, 97-105. https://doi.org/10.1007/978-3-66204482-7_8

Vélez-Rubio GM, Estrades A, Fallabrino A, Tomás J (2013) Marine turtle threats in Uruguayan waters: Insights from 12 years of stranding data. Marine Biology 160(11): 27972811. https://doi.org/10.1007/s00227-013-2272-y

Velozo RS, Schiavetti A, Dórea-Reis LW (2009) Analysis of subantarctic fur seal (Arctocephalus tropicalis) records in Bahia and Sergipe, north-eastern Brazil. Marine Biodiversity Records 2: E117. https://doi.org/10.1017/S1755267209000980

Werneck MR, Almeida LG, Baldassin P, Guimarães S, Nunes LA, Lacerda PD, Oliveira ALM (2018) Sea turtle beach monitoring program in Brazil. Reptiles and Amphibians. https://doi.org/10.5772/intechopen.76647

Ylitalo GM, Collier TK, Anulacion BF, Juaire K, Boyer RH, Silva DAM, Stacy BA (2017) Determining oil and dispersant exposure in sea turtles from the northern Gulf of Mexico resulting from the Deepwater Horizon oil spill. Endangered Species Research 33: 9-24. https://doi.org/10.3354/esr00762 